\title{
Transport and cytotoxicity of the anticancer drug 3-bromopyruvate in the yeast Saccharomyces cerevisiae
}

\author{
Pawel Lis • Marek Zarzycki • Young H. Ko • \\ Margarida Casal • Peter L. Pedersen • Andre Goffeau • \\ Stanisław Ulaszewski
}

Received: 3 January 2012 / Accepted: 17 January 2012 /Published online: 23 February 2012

(C) The Author(s) 2012. This article is published with open access at Springerlink.com

\begin{abstract}
We have investigated the cytotoxicity in Saccharomyces cerevisiae of the novel antitumor agent 3-bromopyruvate (3-BP). 3-BP enters the yeast cells through the lactate/pyruvate $\mathrm{H}^{+}$symporter Jen $1 \mathrm{p}$ and inhibits cell growth at minimal inhibitory concentration of $1.8 \mathrm{mM}$ when grown on non-glucose conditions. It is not submitted to the efflux pumps conferring Pleiotropic Drug Resistance in yeast. Yeast growth is more sensitive to 3-BP than Gleevec (Imatinib methanesulfonate) which in contrast to 3-BP is submitted to the PDR network of efflux pumps. The sensitivity of yeast to 3-BP is increased considerably by mutations or chemical treatment by buthionine sulfoximine that decrease the intracellular concentration of glutathione.
\end{abstract}

P. Lis $\cdot$ M. Zarzycki $\cdot$ S. Ułaszewski $(\bowtie)$

Institute of Genetics and Microbiology, University of Wroclaw, Przybyszewskiego 63/77,

51-148 Wroclaw, Poland

e-mail: stanislaw.ulaszewski@microb.uni.wroc.pl

Y. H. Ko

300 Redland Court, Suite 212,

Owings Mills, MD 21117, USA

M. Casal

Department of Biology, Molecular and Environmental Biology Centre (CBMA), University of Minho,

4710 - 057 Braga, Portugal

\section{P. L. Pedersen}

Department of Biological Chemistry, John Hopkins University

School of Medicine,

Baltimore, MD 21205-2185, USA

\section{A. Goffeau $(\square)$}

Institut des Sciences de la Vie, Université Catholique de

Louvain-la-Neuve, 1, Place de l'Université,

1348 Louvain-la-Neuve, Belgium

e-mail: andre.goffeau@uclouvain.be
Keywords Saccharomyces cerevisiae - 3-bromopyruvate · Multidrug resistance - Transport - Glutathione - Gleevec . Anti-cancer chemotherapy
Abbreviations
3-BP 3-bromopyruvate
BSO Buthionine sulfoximine
GSH Glutathione
YNB Yeast nitrogen base
HX2 Hexokinase 2
MIC Minimal inhibitory concentration
PDR Pleiotropic drug resistance

\section{Introduction}

The small molecule 3-bromopyruvate (3-BP) inhibits both cell motility and pyruvate release in African Trypanosomes (Barnard et al. 1993) as well as the growth of Toxoplasma gondii (De Lima et al. 2011). Recently it was found that 3-BP is a novel anticancer drug that reduces dramatically the level of ATP in a variety of cancer models followed by cell death (Ko et al. 2004; Mathupala et al. 2010; Ko et al. 2001; Qin et al. 2010; Porporato et al. 2010). This indicates that 3-BP inhibits both mitochondrial and glycolytic ATP production (Mathupala et al. 2010; Ko et al. 2001; Geschwind et al. 2002) in malignant tumors that are submitted to the "Warburg effect" characterized by increased glycolysis and abundant production of lactate in the presence of oxygen. The "Warburg effect" has been related to overexpression of hexokinase 2 (HX2) and its binding to mitochondria (Ko et al. 2001; Geschwind et al. 2002; Mathupala et al. 2009; Pedersen 1978; Pedersen 2007). It also involves the monocarboxylate transporters MCT1 \& MCT4 and the mitochondrial phosphate carrier (PIC) (Mathupala et al. 
2010; Izumi et al. 2011; Mathupala et al. 2006). However, how 3-BP selectively affects only cancer cells is not understood.

In this study we have examined the transport and the mechanism of cytotoxicity of 3-BP in the yeast Saccharomyces cerevisiae. This non pathogenic, unicellular eukaryotic model possesses uniquely sensitive genetic and genomic tools (Goffeau et al. 1996) that can be indicative of similar modifications occurring in the human system (Karathia et al. 2011; Mager and Winderickx 2005) including those involved in cancer chemotherapy (Suter et al. 2006; Cardenas et al. 1999; Dylag et al. 2010; Kurtz et al. 2005). We report that 3-BP is toxic to yeast growth. Its major transporter is the lactate/pyruvate permease Jen1p. 3-BP is not submitted to the efflux pumps involved in the Pleiotropic Drug Resistance (PDR) network. Its intracellular cytotoxicity is strongly modulated by the level of reduced glutathione (GSH) that can be decreased by mutations in the pathway for GSH synthesis or by treatment with buthionine sulfoximine (BSO).

\section{Materials and methods}

Strains and growth conditions

The yeast Saccharomyces cerevisiae haploid strains used in this work are isogenic to W303-1A, BY4741 and US50-18C parental strains, described in Table 1. Strains were grown at $28^{\circ} \mathrm{C}$ in standard rich (YPD) medium or in synthetic minimal medium (YNB) containing $0.67 \%$ yeast nitrogen base without aminoacids. The minimal YNB media was supplemented, when necessary, with appropriate aminoacids and/or adenine and uracil to a final concentration of $20 \mu \mathrm{g} / \mathrm{ml}$ and with $2 \%$ sucrose, glucose, galactose or mannose. Complete medium: $1 \%$ Bacto-peptone plus $1 \%$ yeast extract with $2 \%$ glucose or with lactic acid contained $0.5 \%$ lactate, $\mathrm{pH}=5$. For plating the media were solidified with $2 \%$ of Bacto-agar. Liquid cultures were grown at $28^{\circ} \mathrm{C}$ and $160 \mathrm{rev} . / \mathrm{min}$.(Kaiser et al. 1994).

Sucrose, galactose, mannose, daunorubicin, rhodamine $6 \mathrm{G}$, glutathione and buthionine sulfoximine were purchased from Sigma-Aldrich (USA); yeast extract, Bacto-peptone, yeast nitrogen base, Bacto-agar were from Difco (USA); Imatinib methanesulfonate was from Haoyuan Chemexpress Co., China. The $\left[{ }^{14} \mathrm{C}\right]$-labeled 3-BP was kindly donated as a gift from Dr. Young H. Ko.

\section{Spot tests}

To determine MIC (minimal inhibitory concentration) of a tested compound toward the selected yeast strain and to compare the relative susceptibility of several strains, the cells were grown to mid-log phase, diluted to $\mathrm{OD}_{600}=0.25$ and spotted $(3 \mu \mathrm{l})$ in 10-fold serial dilutions onto the agar plates containing various concentrations of a tested compound. Plates were incubated at $28^{\circ} \mathrm{C}$ for $72-120 \mathrm{~h}$ and photographed. The sensitivity assays were repeated a minimum of three times. Differences in growth show variability of the tested strain in their susceptibility to the tested inhibitor (Kaiser et al. 1994).

\section{Radioactive substrate transport assay}

The uptake of the $\left[{ }^{14} \mathrm{C}\right]$-labeled 3-BP was carried out by the method reported for L-lactate transport by Casal et al. (Casal et al. 1999). Cells were grown to exponential phase at $28^{\circ} \mathrm{C}$ in rich (YPD) medium with $2 \%$ glucose. The cells were harvested, washed twice with ice-cold de-ionized water, resuspended in rich medium with lactic acid and incubated for $4 \mathrm{~h}$. After incubation cells were harvested, washed twice and resuspended in ice-cold de-ionized water to a final concentration of $200 \mathrm{mg} / \mathrm{ml}$ (wet weight). Aliquots of $10 \mu \mathrm{l}$ of cells were incubated for $30 \mathrm{~s}$ with different concentrations of the radioactive $\left[{ }^{14} \mathrm{C}\right]$-labeled 3 -BP in phosphate buffer at $30^{\circ} \mathrm{C}$. The reaction was stopped with ice-cold water and the suspension was filtrated on nitrocellulose Whatman filters using a vacuum filtration box (Hoefer, USA). Radioactivity of each sample was measured using a scintillation fluid (Perkin-Elmer) and a scintillation counter Beckman LS100. All charts and calculations were made using GraphPad Prism 5 program.

\section{Determination of reduced glutathione}

The yeast metabolite extracts were prepared according to Gonzales et al. (Gonzalez et al. 1997). The $5 \mathrm{ml}$ overnight yeast cultures grown on minimal medium with sucrose up to $\mathrm{OD}_{600}=1.5-1.8$ were centrifuged and added to $5 \mathrm{ml}$ of the buffered, boiling ethanol $(75 \%$ ethanol, $70 \mathrm{mM}$ HEPES, $\mathrm{pH}$ 7.5). After incubation for $3 \mathrm{~min}$ at $80^{\circ} \mathrm{C}$, the samples were cooled on ice for $3 \mathrm{~min}$ and the volume of the extraction mixture was reduced by evaporation for $3 \mathrm{~h}$ at $45^{\circ} \mathrm{C}$. The residue was re-suspended in $250 \mu \mathrm{l}$ of double distilled water and centrifuged for $5 \mathrm{~min}$, at $14,000 \mathrm{rpm}$ to remove the insoluble material. The whole solubilized sample was added to $2.5 \mathrm{ml}$ of $0.1 \mathrm{M}$ sodium phosphate buffer $(\mathrm{pH} 8.0)$ and mixed and $50 \mu \mathrm{l}$ of $4 \mathrm{mg} / \mathrm{ml}$ DTNB (5,5'-dithio-bis-[2-nitrobenzoic acid]) was added (Ellman 1959). The reaction was developed for $15 \mathrm{~min}$ and the absorbance at $412 \mathrm{~nm}$ was measured with a Varian Cary 300 Spectrophotometer in the the double beam mode using $2.75 \mathrm{ml}$ of the described sodium phosphate buffer with $50 \mu \mathrm{l}$ of $4 \mathrm{mg} / \mathrm{ml}$ DTNB as the reference. The final concentration of the glutathione in the sample was determined on the basis of a standard curve using purchased glutathione as standard. 
Table 1 Yeast strains used

\begin{tabular}{|c|c|c|c|}
\hline Strain & Background & Description and usage & References \\
\hline W303-1A & $\begin{array}{l}\text { W303-1A; (ade2-1, leu2-112, } \\
\text { his3-11,15, trp1-1, ura3-1) }\end{array}$ & $\begin{array}{l}\text { Wild-type strain, isogenic to BLC203 except } \\
\text { for the presence of JEN1. }\end{array}$ & $\begin{array}{l}\text { Thomas et al.(Thomas } \\
\text { and Rothstein 1989). }\end{array}$ \\
\hline BLC203 ( $\triangle \mathrm{JEN} 1)$ & $\begin{array}{l}\text { W303-1A; (ade2-1, leu2-112, } \\
\text { his3-11,15, trp1-1, ura3-1, } \triangle J E N 1)\end{array}$ & $\begin{array}{l}\text { Strain in which the lactate transporter gene } \\
J E N 1 \text { is deleted. Used to test 3-BP transport } \\
\text { as a negative control. }\end{array}$ & $\begin{array}{l}\text { Casal et al. } \\
\text { (Casal et al. 1999). }\end{array}$ \\
\hline EM01 & US50-18 C; (ura3, his1) & $\begin{array}{l}\text { Wild-type strain, isogenic to US50-18 } \\
\text { C and AD strains. }\end{array}$ & $\begin{array}{l}\text { From Maciaszczyk- } \\
\text { Dzubińska E. } \\
\text { [not published] }\end{array}$ \\
\hline US50-18 C & US50-18 C; (ura3, his1, pdr1-3) & $\begin{array}{l}\text { Strain with the activating mutation } p d r l-3 \text { in the } \\
\text { gene encoding the transcription factor Pdrlp. } \\
\text { This strain is hyper-resistant to all drugs which } \\
\text { are Pdrp substrates. }\end{array}$ & $\begin{array}{l}\text { Balzi et al. } \\
\text { (Balzi et al. 1987). }\end{array}$ \\
\hline AD1-3 & $\begin{array}{l}\text { US50-18 C; (ura3, his1, pdr1-3, } \\
\quad \Delta y o r 1, \Delta s n q 2, \Delta p d r 5)\end{array}$ & $\begin{array}{l}\text { Strain with deletion of } 3 \text { genes encoding the } \\
\text { major Pdr transporters Yorlp, Snq } 2 \mathrm{p} \text { and } \\
\text { Pdr5p. The } p d r 1-3 \text { mutation results in } \\
\text { overexpression of the non-deleted } \\
\text { genes controlled by PDRI }\end{array}$ & $\begin{array}{l}\text { Decottignies et al. } \\
\text { (Decottignies et al. 1988). }\end{array}$ \\
\hline AD1-7 & $\begin{array}{l}\text { US50-18 C; (ura3, hisl, pdrl-3, } \\
\quad \Delta y o r 1, \Delta s n q 2, \Delta p d r 5, \Delta p d r 10 \\
\Delta p d r 11, \Delta y c f 1, \Delta p d r 3)\end{array}$ & $\begin{array}{l}\text { Strain with deletion of } 6 \text { genes encoding the } \\
\text { transporters Yor } 1 \mathrm{p}, \text { Snq2p, Pdr5p, Pdr10p, } \\
\text { Pdr11p, Ycflp and the transcription factor } \\
\text { Pdr3p.The } p d r 1-3 \text { mutation results in } \\
\text { overexpression of the non-deleted } \\
\text { genes controlled by PDR1 }\end{array}$ & $\begin{array}{l}\text { Decottignies et al. } \\
\text { (Decottignies et al. 1988) }\end{array}$ \\
\hline AD1-8 & $\begin{array}{l}\text { US50-18 C; (ura3, his 1, pdr1-3, } \Delta y o r 1, \\
\quad \Delta s n q 2, \Delta p d r 5, \Delta p d r 10, \Delta p d r 11 \\
\Delta p d r 15, \Delta y c f 1, \Delta p d r 3)\end{array}$ & $\begin{array}{l}\text { Strain with deletion of } 7 \text { genes encoding the } \\
\text { transporters Yor } 1 \mathrm{p}, \text { Snq2p, Pdr5p, Pdr10p, } \\
\text { Pdr11p, Pdr15p, Ycflp and the transcription } \\
\text { factor Pdr3p. The } p d r 1-3 \text { mutation results in } \\
\text { overexpression of the non-deleted genes } \\
\text { controlled by PDR1. }\end{array}$ & $\begin{array}{l}\text { Decottignies et al. } \\
\text { (Decottignies et al. 1988) }\end{array}$ \\
\hline AD1-9 & $\begin{array}{l}\text { US50-18 C; (ura3, his 1, pdr1-3, } \Delta y o r 1, \\
\quad \Delta s n q 2, \Delta p d r 5, \Delta p d r 10, \Delta p d r 11 \\
\Delta p d r 15, \Delta y c f 1, \Delta p d r 3, \Delta p d r 1)\end{array}$ & $\begin{array}{l}\text { Strain with deletion of } 7 \text { genes encoding the } \\
\text { transporters Yor } 1 \mathrm{p}, \text { Snq2p, Pdr5p, Pdr10p, } \\
\text { Pdr11p, Pdr15p, Ycflp and both transcription } \\
\text { factors } P d r 1 p \text { and } P d r 3 p \text {. }\end{array}$ & $\begin{array}{l}\text { Decottignies et al. } \\
\text { (Decottignies et al. 1988). }\end{array}$ \\
\hline BY4741 & $\begin{array}{l}\mathrm{BY} 4741 ;(\text { his } 3 \Delta ; \text {;eu } 2 \Delta ; \\
\quad \text { met15 } \Delta ; \text { ura } 3 \Delta)\end{array}$ & $\begin{array}{l}\text { Parental strain, isogenic to } \Delta \mathrm{GSH} 1, \Delta \mathrm{GSH} 2 \\
\text { and } \Delta \mathrm{GLR} 1 \text { strains, encoding enzymes } \\
\text { involved in glutathione biosynthesis. }\end{array}$ & From EUROSCARF \\
\hline$\Delta \mathrm{GSH} 1$ & $\begin{array}{l}\text { BY4741; (his } 3 \Delta ; \text { leu } 2 \Delta ; \text { met15 } \Delta \text {; } \\
\quad \text { ura } 3 \Delta ; \text { GSH1 } \Delta)\end{array}$ & $\begin{array}{l}\text { Strain with deletion of the gene encoding } \\
\gamma \text {-glutamylcysteine synthetase, which catalyzes } \\
\text { the first step in glutathione biosynthesis } \\
\text { (Ohtake et al. 1990). }\end{array}$ & From EUROSCARF \\
\hline$\Delta \mathrm{GSH} 2$ & $\begin{array}{l}\text { BY4741; (his } 3 \Delta ; \text { leu2 } \Delta ; \\
\quad \text { met } 15 \Delta ; \text { ura } 3 \Delta ; \text { GSH2 } \Delta)\end{array}$ & $\begin{array}{l}\text { Strain with deletion of the gene encoding } \\
\text { glutathione synthetase, which catalyzes } \\
\text { the synthesis of glutathione from } \\
\text { gamma-glutamylcysteine and glycine } \\
\text { (Ohtake et al. 1990). }\end{array}$ & From EUROSCARF \\
\hline$\Delta \mathrm{GLR} 1$ & $\begin{array}{l}\text { BY4741; (his } 3 \Delta ; \text { leu2 } \Delta ; \\
\quad \text { met } 15 \Delta ; \text { ura } 3 \Delta ; \text { GSH } 2 \Delta)\end{array}$ & $\begin{array}{l}\text { Strain with deletion of the gene encoding } \\
\text { glutathione reductase, which converts oxidized } \\
\text { glutathione to the reduced form GSH } \\
\text { (Outten et al. 2005). }\end{array}$ & From EUROSCARF \\
\hline
\end{tabular}

\section{Results and discussion}

3-bromopyruvic acid is taken up in yeast cells by the glucose-repressible lactate /pyruvate transporter Jen $1 \mathrm{p}$

At external $\mathrm{pH}=5.0$ of minimal (YNB) medium the minimal inhibitory concentration (MIC) of $1.95 \mathrm{mM} 3-\mathrm{BP}$ inhibits the growth of the parental strain W303-1A (Fig. 1a).
The yeast displays at least two distinct transporters involved in the uptake of monocarboxylates across the plasma membrane: the Lactate/Pyruvate: $\mathrm{H}^{+}$Symporter Jen $1 \mathrm{p}$ and the Acetate: $\mathrm{H}^{+}$Transporter (Ady2p). Additionally, the yeast genome encodes five members of the Monocarboxylate Porter (MCP) Family (De Hertogh et al. 2002), but their role in importing monocarboxylic acids has not been proven (Makuc et al. 2001; Reihl and Stolz 2005). 
Fig. 1 Differences in growth sensitivity of the parental strain (W303-1A) and $\triangle J E N 1$ mutant to 3-bromopyruvate on media (YNB) with a non-repressing (sucrose/galactose) and repressing (glucose/mannose) carbon source
A. Minimal (YNB) medium with sucrose/galactose as a carbon source

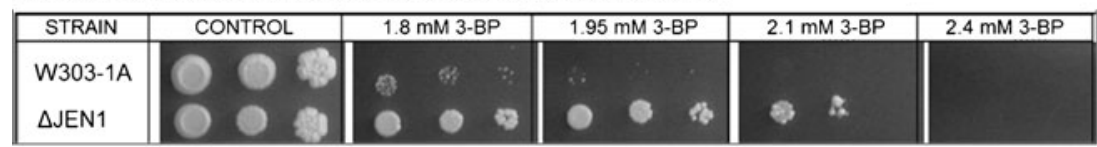

B. Minimal (YNB) medium with glucose/mannose as a carbon source

\begin{tabular}{|c|c|c|c|c|c|}
\hline STRAIN & CONTROL & $1.8 \mathrm{mM} \mathrm{3-BP}$ & $1.95 \mathrm{mM} 3-\mathrm{BP}$ & $2.1 \mathrm{mM} 3-\mathrm{BP}$ & $2.4 \mathrm{mM} 3-\mathrm{BP}$ \\
\hline W303-1A & 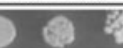 & 182 & s. & 0 \% & 0 \\
\hline$\triangle \mathrm{J} E N 1$ & & & & 5 & 0 \\
\hline
\end{tabular}

The Jen $1 p$ transporter was an obvious candidate for the 3-BP transporter as it transports pyruvate as well as lactate (Casal et al. 1999; Cassio et al. 1987). Figure 1a shows that the growth of the $\triangle J E N 1$ strain is more resistant to 3-BP $(\mathrm{MIC}=2.4 \mathrm{mM})$ than the parental strain W303-1A $(\mathrm{MIC}=$ $1.95 \mathrm{mM}$ ). This effect is observed under culture conditions (sucrose/galactose) that derepress Jen1p but is not visible in medium containing glucose/mannose. Indeed, Fig. 1b shows that in this medium a MIC higher than $2.4 \mathrm{mM}$ is observed both for parental W303-1A and $\triangle J E N 1$ strains probably due to the well known glucose repression of Jen $1 p$ (Casal et al. 1999).

Figure 2 shows that the uptake of $\left[{ }^{14} \mathrm{C}\right] 3-\mathrm{BP}$ is markedly decreased in the $\triangle J E N 1$ strain compared to the parental strain W303-1A. Transport parameters in the parental strain were consistent with Michaelis-Menten kinetics with a $\mathrm{Km}=2 \mathrm{mM}$ 3 -BP and $\mathrm{a} \mathrm{V}_{\max }=0.57 \mathrm{nmol} 3-\mathrm{BP}$ taken up $/ \mathrm{min} \times 10^{6}$ cells. Uptake rate in the $\triangle J E N 1$ strain is over 2-fold lower with a $\mathrm{V}_{\text {max }}=0.22 \mathrm{nmol} / \mathrm{min} \times 10^{6}$ cells. A small amount of 3-BP is transported in the $\triangle \mathrm{JEN} 1$ strain. This may be due to the simple diffusion combined to weak activities of other transporters such as the acetate transporter Ady2p and the monocarboxylate tansporters Mch1p to Mch5p, unrelated to Jen 1p (data not shown). It has to be noted however that there is no lactate/pyruvate transporter similar to Jen1p in mammalian cells. It remains thus to identify the monocarboxylate transporters which take up specifically 3 -BP in cancer cells.

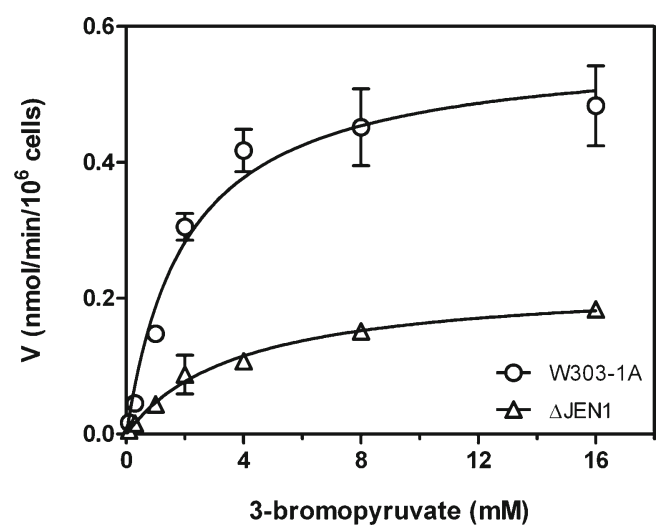

Fig. 2 Transport of $\left[{ }^{14} \mathrm{C}\right] 3-\mathrm{BP}$ in $\mathrm{W} 303-1 \mathrm{~A}$ and $\triangle \mathrm{JEN} 1$ strains; $\left(\mathrm{Km}=2 \mathrm{mM} 3-\mathrm{BP}, \mathrm{V}_{\max }=0.57 \mathrm{nmol} 3-\mathrm{BP} / \mathrm{min} \times 10^{6}\right.$ cells
The Yeast PDR network is not involved in conferring resistance to 3-bromopyruvate

In Saccharomyces cerevisiae the Pleiotropic Drug Resistance network of genes confers resistance to a variety of small cytotoxic molecules by activating their cellular efflux (Cannon et al. 2009; Prasad and Goffeau 2012). Single and multiple deletions in $\mathrm{ABC}$ efflux pumps and of their transcription regulators renders the cells very sensitive to inhibitiors. We have compared the growth of the various PDR-hypersensitive deleted mutants AD1-3, AD1-7, AD1-8, AD1-9 and of the upregulated multidrug resistant mutant US50-18 C (Balzi et al. 1987; Decottignies et al. 1988) compared to the EM01 parental isogenic strain on media containing various concentrations of 3-BP. Figure 3a shows that neither 3-BP-resistance nor sensitive phenotype were observed. 3-BP is thus not a substrate of any of the tested drug-efflux pumps belonging to the $\mathrm{ABC}$ family of transporters. The phenotype is totally different when comparing growth (Fig. 3c and d) in the presence of the well known multidrug substrates daunorubicin and rhodamine $6 \mathrm{G}$ (Kolaczkowski et al. 1998; Decottignies et al. 2001). Figure 3b shows that the well know anticancer drug Gleevec (Imatinib methanesulfonate) (Hoepfl et al. 2002; Cohen et al. 2002) inhibits growth at concentrations similar to those which are toxic for 3-BP. However, the parental strain EM01 is more resistant $(\mathrm{MIC}=2.2 \mathrm{mM})$ to Imatinib methanesulfonate than the Pdrp-activated strain US50-18 C (MIC=1.8 mM) while the supersensitive $\mathrm{AD}$ deleted strains are more sensitive to Imatinib methanesulfonate (MIC $1.6 \mathrm{mM}$ ) than the parental EM01. Moreover, an aqua-Molar content of 3-BP is almost 4 times lower than Gleevec (M.W. 166.96 versus 589.71, respectively). From a practical point of view it is worth to mention that the first drug is much cheaper. This important new finding suggests that 3-BP is less likely to develop multidrug resistance in the course of chemiotherapy (Endicott and Ling 1989; Gottesman and Pastan 1993) than Imatinib methanesulfonate and many other drugs (such as daunorubicin, vinblastine and mitomycine).

Intracellular concentration of reduced glutathione correlates with 3-bromopyruvate sensitivity

In Fig. 4 we have tested the susceptibility to 3-BP of three strains defective in glutathione metabolism (Ohtake et al. 
Fig. 3 Differences in

sensitivity of PDR-mutants to 3-BP, Imatinib methanesulfonate, daunorubicin and rhodamine 6 G. Minimal medium (YNB) with sucrose

\section{A. 3-bromopyruvic acid}

\begin{tabular}{|c|c|c|c|c|c|c|}
\hline STRAIN & CONTROL & $\begin{array}{c}1.08 \mathrm{mM} \\
3-\mathrm{BP}\end{array}$ & $\begin{array}{c}1.26 \mathrm{mM} \\
3-\mathrm{BP}\end{array}$ & $\begin{array}{c}1.44 \mathrm{mM} \\
3-\mathrm{BP}\end{array}$ & & $\begin{array}{c}1.62 \mathrm{mM} \\
3-\mathrm{BP}\end{array}$ \\
\hline EM01 & wit & 0 & 0.3 & $\%$ & & \\
\hline US50-18C & 路 & $0 \Rightarrow k_{k}$ & 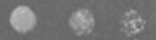 & $8 \div$ & & \\
\hline$A D 1-3$ & $0<$ 级 & $00 \%$ & $00 \%$ & Q $*$ & $\dot{3}$ & \\
\hline$A D 1-7$ & 00 & $\theta \%$ & $0 \%$ & (6) 8 & s. & है \\
\hline$A D 1-8$ & 0 & Q. 6 & (2) 学 & e & 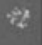 & $\therefore$ \\
\hline AD1-9 & $\Leftrightarrow$ & $0 \%$ & 08 & & & \\
\hline
\end{tabular}

B. Imatinib methanesulfonate

\begin{tabular}{|c|c|c|c|c|c|}
\hline STRAIN & CONTROL & $\begin{array}{c}1.6 \mathrm{mM} \\
\text { Imatinib mesylate }\end{array}$ & $\begin{array}{c}1.8 \mathrm{mM} \\
\text { Imatinib mesylate }\end{array}$ & $\begin{array}{c}2.2 \mathrm{mM} \\
\text { Imatinib mesylate }\end{array}$ & $\begin{array}{c}2.6 \mathrm{mM} \\
\text { Imatinib mesylate }\end{array}$ \\
\hline EM01 & & 4 & 00 & 8 & \\
\hline US50-18C & & as & C & & \\
\hline AD 1-3 & & 9 & & & 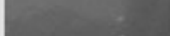 \\
\hline AD 1-7 & 3 & 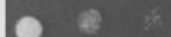 & & & \\
\hline AD1-8 & 5 & bे & & & \\
\hline$A D 1-9$ & 8 & 83 之 & & & \\
\hline
\end{tabular}

\section{Daunorubicin}

\begin{tabular}{|c|c|c|c|c|c|}
\hline STRAIN & CONTROL & $\begin{array}{c}5 \mu \mathrm{M} \\
\text { daunorubicin }\end{array}$ & $\begin{array}{c}20 \mu \mathrm{M} \\
\text { daunorubicin }\end{array}$ & $\begin{array}{c}40 \mu \mathrm{M} \\
\text { daunorubicin }\end{array}$ & $\begin{array}{c}80 \mu \mathrm{M} \\
\text { daunorubicin }\end{array}$ \\
\hline EM01 & & 08 s & (2) & c) 8 & \\
\hline US50-18C & & 083 & 085 & 0 & s8 \\
\hline$A D 1-3$ & 6 & 8 & & & 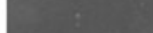 \\
\hline$A D 1-7$ & 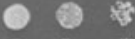 & & $*$ & & \\
\hline AD1-8 & $c^{10}$ & & & & \\
\hline AD1-9 & & y: & & & \\
\hline
\end{tabular}

\section{Rhodamine 6G}

\begin{tabular}{|c|c|c|c|c|c|c|}
\hline STRAIN & CONTROL & $\begin{array}{c}2 \mu \mathrm{M} \\
\text { rhodamine } 6 \mathrm{G}\end{array}$ & $\begin{array}{c}10 \mu \mathrm{M} \\
\text { rhodamine } 6 \mathrm{G}\end{array}$ & $\begin{array}{c}40 \mu \mathrm{M} \\
\text { rhodamine } 6 \mathrm{G}\end{array}$ & $\begin{array}{c}100 \mu \mathrm{M} \\
\text { rhodamine } 6 \mathrm{G}\end{array}$ & $\begin{array}{c}150 \mu \mathrm{M} \\
\text { rhodamine } 6 \mathrm{G}\end{array}$ \\
\hline EM01 & 46 & $28 \%$ & 00 क & $\mathrm{O}$ 황 & $8<$ & $O$ \\
\hline US50-18C & & 8 \& & $00 \Rightarrow$ & 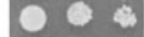 & $0<\%$ & 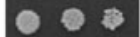 \\
\hline AD1-3 & $00 \mathrm{~s}$ & 0.4 & 08 & g & - & \\
\hline AD1-7 & $00 *$ & & & & & \\
\hline AD1-8 & 00 야 & & & & & \\
\hline AD1-9 & 00 का & & & & & \\
\hline
\end{tabular}

\begin{tabular}{|c|c|c|c|c|c|c|c|}
\hline STRAIN & CONTROL & $\begin{array}{c}0.03 \mathrm{mM} \\
3 . \mathrm{BP}\end{array}$ & $\begin{array}{c}0.3 \mathrm{mM} \\
3 . \mathrm{BP}\end{array}$ & $\begin{array}{c}0.6 \mathrm{mM} \\
3 . \mathrm{BP}\end{array}$ & $\begin{array}{c}0.9 \mathrm{mM} \\
3-\mathrm{BP}\end{array}$ & $\begin{array}{c}1.2 \mathrm{mM} \\
3 \mathrm{BP}\end{array}$ & $\begin{array}{c}1.5 \mathrm{mM} \\
3-\mathrm{BP}\end{array}$ \\
\hline BY 4741 & 003 & 00 에 & 00 & 005 & 8 跑 & $0<*$ & 0 \& 12 \\
\hline$\triangle \mathrm{GSH} 1$ & & & & & & & \\
\hline$\triangle \mathrm{GSH} 2$ & 0.5 & Q & & & & & \\
\hline$\triangle G L R 1$ & 0 & $\mathrm{C}$ & 3 & 6 & O & $\mathrm{O}$ & \\
\hline
\end{tabular}

A. 3-bromopyruvic acid

Fig. 5 Influence of $5 \mathrm{mM}$ BSO (buthionine sulfoximine) to sensitivity to 3-bromopyruvate. Minimal (YNB) medium with sucrose
Fig. 4 Sensitivity of three strains defective in glutathione metabolism ( $\triangle \mathrm{GSH} 1, \Delta \mathrm{GSH} 2$, $\Delta$ GLR1) to 3-BP, compared to the parental strain (BY4741)

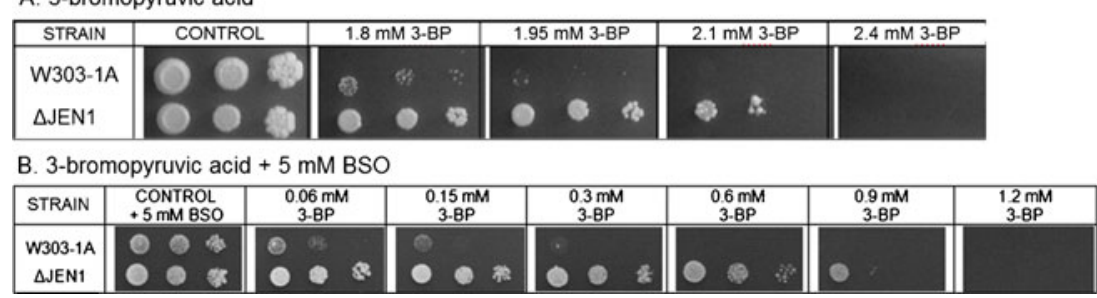


Fig. 6 Correlation of 3-BP sensitivity (MIC values) for BY4741, $\Delta$ GSH1, $\Delta$ GSH2, $\Delta$ GLR1 strains and BY4741 strain grown on medium supplemented with $5 \mathrm{mM}$ BSO, and the relative intracellular levels of reduced glutathione in these strains

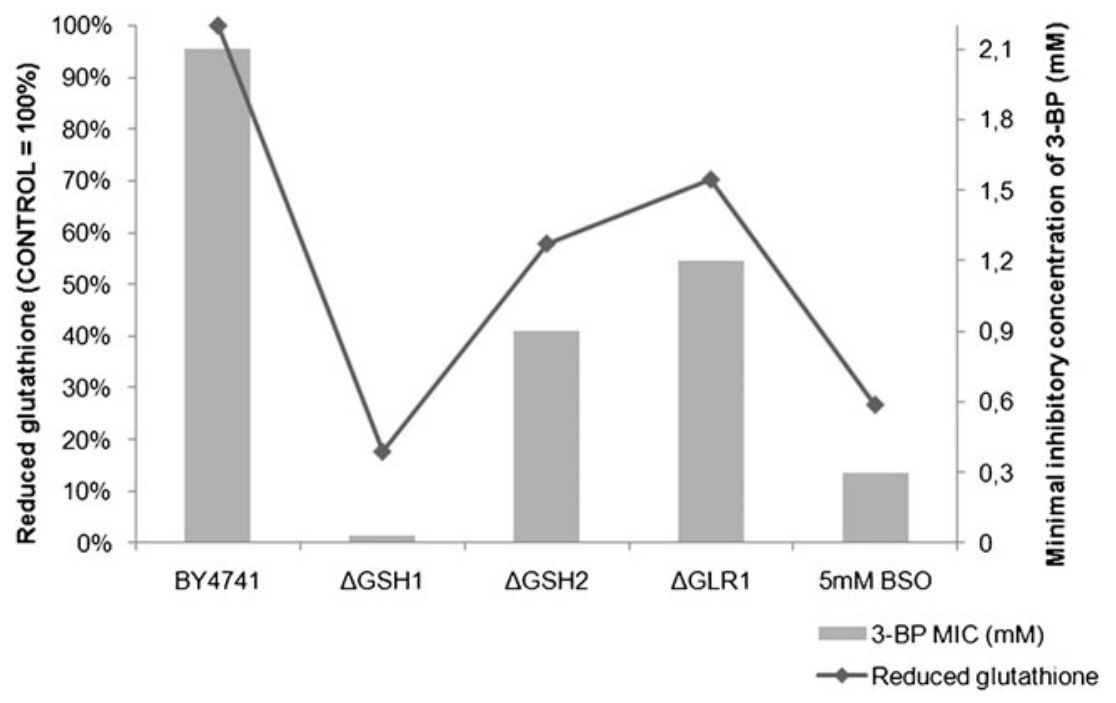

1990; Outten et al. 2005). Growth of a strain with deletion of the gene encoding gamma-glutamylcysteine synthetase $(G S H 1)$, which catalyses the first step in glutathione biosynthesis is strongly weakened even on medium without 3-BP. It is totally inhibited by the very low concentrations of $0.03 \mathrm{mM}$ 3-BP. Difference in growth between the strain deleted in the GSH2 gene (encoding glutathione syntethase, which catalyzes the final step of synthesis of glutathione from gammaglutamylcysteine and glycine) and parental strain is also clearly visible on medium with 3 -BP $(\mathrm{MIC}=0.9 \mathrm{mM})$, with no significant difference on control medium $(\mathrm{MIC}=2.1 \mathrm{mM})$. Deletion of the GLR1 gene (encoding glutathione reductase) also increased the sensitivity to $3-\mathrm{BP}(\mathrm{MIC}=1.5 \mathrm{mM})$.

Figure 5 shows that $0.5 \mathrm{mM}$ buthionine sulfoximine (BSO), a known inhibitor of gamma-glutamylcysteine synthetase, (Reliene and Schiestl 2006) increases about 30 times the susceptibility of the parental yeast cells to 3-BP indicating a spectacular synergistic toxic effect. As expected the deletion of the JEN1 gene restores resistance to 3-BP. This shows that BSO acts intracellularly. Notably the cytotoxicity of doxorubicin shown to be enhanced by BSO has also been reported in multi-drug resistant cells from human breast tumor (Dusre et al. 1989). Figure 6 shows a strong correlation between the intracellular level of GSH and the sensitivity to 3-bromopyruvate. These results indicate that glutathione plays a significant role in resistance to 3-BP in yeast, either directly through interaction with 3-BP or indirectly. An amount of $2 \mathrm{mM}$ BSO treatment resulted in a $45 \%$ lower GSH and 30\% higher frequency of genomic DNA deletions during mouse development (Reliene and Schiestl 2006). As BSO in minimally cytotoxic doses has limited secondary effects both on yeast (this study) and mammalian cells one can conclude that 3-BP in combination with BSO might be useful in anticancer therapy.
Acknowledgments The authors are indebted to dr Ewa MaciaszczykDziubińska for the generous gift of strain EM01, and Joseph Nader (Institut Sciences de la Vie, Université Catholique de Louvain, Louvain-la-Neuve, Be.) for helping with transport assay. Our thanks are due also to Marta Lis and Pawel Łysyganicz for technical assistance. This study was supported by the Ministry of Science and Higher Education (Poland) within of "Statutory Research". PLP acknowledges support from NIH grant CA10951.

Conflict of interest The authors declare that they have no conflict of interest.

Open Access This article is distributed under the terms of the Creative Commons Attribution License which permits any use, distribution, and reproduction in any medium, provided the original author(s) and the source are credited.

\section{References}

Balzi E, Chen W, Ulaszewski S, Capieaux E, Goffeau A (1987) The multidrug resistance gene PDR1 from Saccharomyces cerevisiae. J Biol Chem 262(35):16871-16879

Barnard JP, Reynafarje B, Pedersen PL (1993) Glucose Catabolism in African Trypanosomes. J Biol Chem 268(5):3661

Cannon RD, Lamping E, Holmes AR, Niimi K, Baret PV, Keniya MV et al (2009) Efflux-mediated antifungal drug resistance. Clin Microbiol Rev 22(2):291-321

Cardenas ME, Cruz MC, Del Poeta M, Chung N, Perfect JR, Heitman J (1999) Antifungal activities of antineoplastic agents: Saccharomyces cerevisiae as a model system to study drug action. Clin Microbiol Rev 12(4):583-611

Casal M, Paiva S, Andrade RP, Gancedo C, Leão C (1999) The lactateproton symport of Saccharomyces cerevisiae is encoded by JEN1. J Bacteriol 181(8):2620-2623

Cassio F, Leão C, van Uden N (1987) Transport of lactate and other short-chain monocarboxylates in the yeast Saccharomyces cerevisiae. Appl Environ Microbiol 53(3):509-513

Cohen MH, Williams G, Johnson JR, Duan J, Gobburu J, Rahman A et al (2002) Approval summary for imatinib mesylate capsules in the 
treatment of chronic myelogenous leukemia. Clin Cancer Res 8 (1):935-942

De Hertogh B, Carvajal E, Talla E, Dujon B, Baret P, Goffeau A (2002) Phylogenetic classification of transporters and other membrane proteins from Saccharomyces cerevisiae. Funct Integr Genom 2 (4-5):154-170

De Lima LPO, De Faria TRB, Portes JA, Pinho NZ, De Souza TG, De Souza, W et al (2011) 3-BrPA And FeHP( $\left.\mathrm{SO}_{4}\right)$. Affect the growth of Toxoplasma gondii and induce the conversion of tachyzoites in bradyzoites during interaction with LLC-MK 2 . Laboratorio de Tecnologia em Bioquimica e Microscopia, UEZO, Rio de Janeiro, RJ.http://www.csbmm2011.com.br/arearestrita/arquivos/16809. pdf. Accessed 2011.

Decottignies A, Grant MA, Nichols JW, de Wet H, McIntosh DB, Goffeau A (1988) ATPase and multidrug transport activities of the overexpressed yeast ABC protein Yorlp. J Biol Chem 273 (20):12612-12622

Decottignies A, Rogers B, Kolaczkowski M, Carvajal E, Balzi E, Conseil $\mathrm{G}$ et al (2001) The pleiotropic drug ABC transporters from Saccharomyces cerevisiae. In: Microbial multidrug efflux. (pp.157-176). Horizon Scientific Press, Wymondham, UK

Dusre L, Mimnaugh G, Myers CE, Sinha BK (1989) Potentiation of doxorubicin cytotoxicity by buthionine sulfoximine in multidrugresistant human breast tumor cells. Cancer Res 49(1):511-515

Dylag M, Pruchnik H, Pruchnik F, Majkowska-Skrobek G, Ułaszewski S (2010) Antifungal activity of organotin compounds with functionalized carboxylates evaluated by the microdilution bioassay in vitro. Med Mycol 48(2):373-383

Ellman GL (1959) Tissue sulfhydryl groups. Arch Biochem Biophys 82(1):70-77

Endicott JA, Ling V (1989) The biochemistry of P-glycoprotein-mediated multidrug resistance. Annu Rev Biochem 58(1):1137-1171

Geschwind JF, Ko YH, Torbenson MS, Magee C, Pedersen PL (2002) Novel therapy for liver cancer: direct intraarterial injection of a potent inhibitor of ATP production. Cancer Res 62(1):3909-3913

Goffeau A, Barrell BG, Bussey H, Davis RW, Dujon B, Feldmann H et al (1996) Life with 6000 Genes. Science, 274(5287), 546 + 563-567

Gonzalez B, François J, Renaud M (1997) A rapid and reliable method for metabolite extraction in yeast using boiling buffered ethanol. Yeast 13(1):1347-1355

Gottesman MM, Pastan I (1993) Biochemistry of multidrug resistance mediated by the multudrug transporter. Annu Rev Biochem 62 (1):385-427

Hoepfl J, Miething C, Grundler R, Gotze KS, Peschel C, Duyster J (2002) Effects of imatinib on bone marrow engraftment in syngenic mice. Leukemia 16(9):1584

Izumi $\mathrm{H}$, Takahashi M, Yramoto H, Nakayama Y, Oyama T, Wang KY et al (2011) Monocarboxylate transporters 1 and 4 are involved in the invasion activity of human lung cancer. Canc Sci 102(5):1007-1013

Kaiser C, Michaelis S, Mitchel AA (1994) Cold Spring Harbor laboratory course manual. Cold Spring Harbor Laboratory Press, Cold Spring Harbor, Methods in yeast genetics

Karathia H, Vilaprinyo E, Sorribas A, Alves R (2011) Saccharomyces cerevisiae as a model organism: a comparative study. PLoS One 6 (2): $1-17$

Ko YH, Pedersen PL, Geschwind JF (2001) Glucose catabolism in the rabbit VX2 tumor model for liver cancer: characterization and targeting hexokinase. Cancer Lett 173(1):83-91

Ko YH, Smith BL, Wang Y, Pomper MG, Rini DA, Torbenson MS et al (2004) Advanced cancers: eradication in all cases using 3- bromopyruvate therapy to deplete ATP. Biochem Biophys Res Comm 5(1):269-275

Kolaczkowski M, Kolaczowska A, Luczynski J, Witek S, Goffeau A (1998) In vivo characterization of the drug resistance profile of the major $\mathrm{ABC}$ transporters and other components of the yeast pleiotropic drug resistance network. Microb Drug Res 4(3):143158

Kurtz JE, Dufour P, Bergerat JP, Exinger F (2005) Saccharomyces Cerevisiae as a genetic model in anticancer therapy. Current Pharmacogenomics 3(1):1-7

Mager W, Winderickx J (2005) Yeast as a model for medical and medicinal research. Trends Pharmacol Sci 26(5):265-273

Makuc J, Paiva S, Schauen M, Kramer R, Andre B, Casal M et al (2001) The putative monocarboxylate permeases of the yeast Saccharomyces cerevisiae do not transport monocarboxylic acids across the plasma membrane. Yeast 18(12):1131-1143

Mathupala SP, Ko YH, Pedersen PL (2006) Hexokinase II: cancer's double-edged sword acting as both facilitator and gatekeeper of malignancy when bound to mitochondria. Oncogene 25(1):47774786

Mathupala SP, Ko YH, Pedersen PL (2009) Hexokinase-2 bound to mitochondria: cancer's stygian link to the "Warburg Effect" and a pivotal target for effective therapy. Semin Canc Biol 19(1):17-24

Mathupala SP, Ko YH, Pedersen P (2010) The pivotal roles of mitochondria in cancer: Warburg and beyond and encouraging prospects for effective therapies. Biochim Biophys Acta 1797 (1): $1225-1230$

Ohtake Y, Satou A, Yabuuchi S (1990) Isolation and characterization of glutathione biosynthesis-deficient mutants in Saccharomyces cerevisiae. Agric Biol Chem 54(12):3145-3150

Outten CE, Falk RL, Culotta VC (2005) Cellular factors required for protection from hyperoxia toxicity in Saccharomyces cerevisiae. Biochem J 388(1):93-101

Pedersen PL (1978) Tumor mitochondria and the bioenergetics of cancer cells. Progr Exp Tumor Res 22(1):190-274

Pedersen PL (2007) Warburg, me and hexokinase2: multiple discoveries of key molecular events underlying one of cancers' most common phenotypes, the "Warburg Effect", i.e., elevated glycolysis in the presence of oxygen. J Bioenerg Biomembr 39(1):211222

Porporato PE, Dhup S, Dadlich RK, Copetti T, Sonveaux P (2010) Anticancer targets in the glycolytic metabolism of tumors: a comprehensive review. Front Pharmacol 2(49):1-18

Prasad R, Goffeau A (2012) Yeast ATP-binding cassette transporters conferring multidrug resistance. Annual Review Microbiology, in press

Qin J-Z, Xin H, Nickoloff BJ (2010) 3-bromopyruvate induces necrotic cell death in sensitive melanoma cell lines. Biochem Biophys Res Comm 396(1):495-500

Reihl P, Stolz J (2005) The monocarboxylate transporter homolog Mch5p catalyzes riboflavin (vitamin B2) uptake in Saccharomyces cerevisiae. J Biol Chem 280(48):39809-39817

Reliene R, Schiestl RH (2006) Glutathione depletion by buthionine sulfoximine induces DNA deletions in mice. Carcinogenesis 27 (2):240-244

Suter B, Auerbach D, Stagljar J (2006) Yeast-based functional genomics and proteomics technologies: the first 15 years and beyond. Biotechniques 40(1):625-644

Thomas BJ, Rothstein R (1989) Elevated recombination rates in transcriptionally active DNA. Cell 58(1):819-830 